\title{
Truth and the Transunto: A Copy of the Holy Shroud in Sixteenth-Century Bologna
}

\begin{abstract}
'Truth and the transunto' investigates the use of a hand-painted copy of the Holy Shroud which found its way to Bologna in the late sixteenth century. Used by the archbishop of Bologna, Alfonso Paleotti (1531-1610) this copy was the source of observations of the body of Christ, in the manner of an autopsy and is presented in Paleotti's book Esplicatione del Lenzuolo [...]. Early modern copies of the Holy Shroud are not however accurate copies, but present seemingly simplified replicas of the original. This article explores how such information, and indeed, level of trust, can come from these copies, which, to the modern eye, seem fallible. Previous studies have excused the strange appearance of these Shroud copies by considering them solely devotional instruments yet as the article shows, Paleotti's use of such an object shows that the copies might be better understood in the context of early modern natural historical studies and illustration. The article draws on scholarship which discusses the emerging interest for visual evidence in early scientific practice and shows how certain types of images and image making practices were able to evoke the idea of presence and clarify the indecipherable. Demonstrating that Paleotti's copy of the Holy Shroud was not just a religious tool, but also an epistemic image, this article shows how Paleotti's use of the term 'transunto' could be used as a valuable tool in gaining a more nuanced understanding of the concept 'copy' in Early Modern Europe.
\end{abstract}

In 1598 Alfonso Paleotti (1531-1610), the Archbishop of Bologna, published Esplicatione del lenzuolo ove fu involto il Signore $[. .],.{ }^{1}$ the first comprehensive book about what is now known in English as the Holy Shroud of Turin. ${ }^{2}$ This relic was and still is by many, believed to be the burial cloth of Christ, as mentioned in the Gospels. ${ }^{3}$ On one of the first pages of the Esplicatione del lenzuolo the reader is provided a large fold-out image of the Holy Shroud ${ }^{4}$

\footnotetext{
${ }^{1}$ The full title of the book is Esplicatione del lenzuolo, oue fu inuolto il Signore, e delle piaghe in esso impresse col suo pretioso sangue confrontate con la Scrittura, Profeti, e Padri. Con la notitia di molte piaghe occulte, e numero de' chiodi. Et con pie meditationi de' dolori della B. Verg.ne. Dell' ill.mo e R.mo Mons. Alfonso Paleotto Arciuesc. di Bologna ad utilità spirituale del suo popolo. From hereon Esplicatione del lenzuolo.

${ }^{2}$ It is known in Italian as 'Sacra Sindone.'

${ }^{3}$ In 1977 tests ruled that the Shroud was a medieval fake. The question of the burial sheet's authenticity is still ongoing, see Turley, K. V 2019. The authenticity of the Shroud does not concern us here as in the period discussed the Shroud was officially accepted by the Catholic Church as a relic of Christ in the 1500s. A linen cloth in which Christ's body is wrapped is mentioned in all the Gospels. For particular reference as burial cloth see John 20: 5-7.

${ }^{4}$ From here on referred to as 'Shroud.'
} 
presented in a two-tone woodcut (FIG. 1). The act of unfolding this large page and seeing the unusual image would have created for the book's reader a sense of being present at the popular ostensions of the Shroud in which the large burial sheet of Christ was unfolded and shown to crowds. For the person holding Paleotti's book, the dimensions of this illustrated page, its intense colour, and the act of unfolding, would have emulated a sense of witnessing the Holy Shroud for themselves, what would have been termed in the early modern period autopsia -

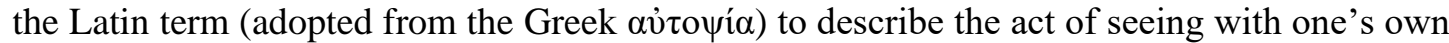
eyes.

Yet, the image of the Shroud in Paleotti's book was no direct copy; one of the most prominent departures from the original Shroud is the missing burn marks from a fire of 1532 . There is also the addition of a lettered key in black ink which is clearly inspired by anatomical illustrations of the same period (FIG. 2). Those black letters point to the function of the Shroud in the book; it is an epistemic image, one which will provide its reader with knowledge. ${ }^{5}$ Paleotti explains precisely this point when he tells his reader that his observations of the Shroud reveal unknown information, with which the truth of Holy Scripture can be better understood. ${ }^{6}$ Should the reader not be convinced of what is being said, Paleotti simply asks them to look at the relevant letter and see for themselves what he sees. The sense of seeing for oneself - seeing what Paleotti has witnessed - gives the reader confidence in what is being divulged.

Reading Esplicatione del Lenzuolo, the reader is under the impression that all of Paleotti's observations were made directly from this unique and prestigious object. His descriptions are so striking and detailed that it is almost as if what Paleotti describes is not an image but the actual body of Christ. Yet the original Shroud was by no means readily available. The Shroud was not an object which one could access easily, even today; locked up in its reliquary in Turin, its inaccessibility heightens its aura and prestige. While it is true that Paleotti had the opportunity to view the Shroud in person when he attended the ostension of the Shroud in 1582 (FIG. 3), he did not start writing Esplicatione del lenzuolo until nine years later. For Paleotti to describe the Shroud with so much detail and so many years after having seen it in person, he would instead have had to rely on another source - a copy rather than the original.

That Paleotti does this is not hidden from his reader. On the very first pages of Esplicatione del lenzuolo, Paleotti describes how, when visiting the sacred burial cloth of Christ in Turin in 1582, a desire had alit in him to obtain his very own copy in the same size:

...Having seen such an admirable thing, there remained inside me the burning desire to obtain a copy [un transunto] of the same size to be able to (by affixing my eyes on it) imprint in my mind those most sacred wounds for the good of my soul, just as the Lord left a memory of Himself made from life [al vivo]. And my desire for this copy was fulfilled not long ago by the effort and kind-

\footnotetext{
5 The term 'epistemic image' is defined by Lorraine Daston as an image which is 'the result of deliberation and choice based on long and expert acquaintance with the phenomena in question and informed by strongly held views about how to seek the truth about them", and are made to replace the phenomena and to be dispersed amongst those who do not have access to the same phenomena but wish to study it. Daston 2015, 18.

${ }^{6}$ See for example the intention of the author in Chapter 1, Paleotti 1598, 3; See also footnote 8 in this contribution.
} 
ness of Cardinal Federico Borromeo who received in his hands a copy faithfully and diligently extracted [elevato] from the original. ${ }^{7}$

This much desired copy comes into Paleotti's hands probably around 1590, not directly from the Savoy family who owned the linen relic, but rather through Cardinal Federico Borromeo (1564-1631). It is worth paying attention to a number of terms in this short description of the Shroud replica Paleotti received. I believe these terms - transunto, elevato and al vivo - reveal a specific way of understanding and interpreting images and their copies. The words to describe what is seen and who it is seen can help to understand how Paleotti is able to trust a copy of the Shroud which would have been painted, not mass produced, and also obtain new information from it. Paleotti explains that "by gazing at [this transunto] often, I have made some considerations and discovered some secrets made clear in the Shroud" (FIG. 4). ${ }^{8}$ The type of information he receives from this copy often contradicts traditional doctrine, and will eventually lead Paleotti to come under scrutiny by the Inquisitor of Bologna and a revision of his book. This demonstrates how much trust he puts into his copy of the Shroud.

Trusting a copy, which is described as "faithfully and diligently extracted from the original," at first poses few problems for the modern viewer. Accurate (that is, what we might term 'faithful') images bearing close resemblance to the prototype is a concept embedded deep in our modern expectations of a 'good' copy and assists our tendency to trust them. This expectation derives from our habit of viewing images produced by either linear perspective or photography which we believe represent the external world just as we think we see them. ${ }^{9}$ Yet Paleotti's description of his copy does not accurately match the reality of how these Shroud copies looked nor the origins of his own copy. As will be argued Paleotti's copy comes neither directly from the original nor looks exactly like it, therefore "faithfully and diligently extracted from the original", is a phrase that needs unpacking. While the phrase confirms the amount of trust Paleotti had in his copy it also contradicts our modern expectancies of a good copy.

That our perception of a trustworthy copy or the relationship between original-copy should diverge from that of the past is well discussed. As several of scholars have noted, the relationship between copy and original is neither fixed nor simply handed down from the past; 'original-copy' is a relationship shaped by, and given meaning in, various social and cultural contexts. ${ }^{10}$ In turn, this relationship governs how much trust we put in copy, and how

\footnotetext{
7 "Veduto c'hebbi cosa tanto ammirabile, restai con acceso desiderio d'haverne un transunto della stessa misura, ove potere (affisandovi gli occhi) così imprimermi nella mente quelle sacratissime piaghe, à Salute dell'anima mia; come esso Sig. lasciovvele entro per memoria di se figurate al vivo. Et essendosi poco tempo fa il mio desiderio adempito per opera, e bontà del Sig. Cardinale Federico Borromeo, al quale n'era pervenuta alle mani una copia elevata fedelmente e diligentemente dall'originale." Paleotti 1598, Unnumbered page in dedication to Pope Clement VIII. The text of Paleotti's book is transcribed here as it is in the book without any modern adaptations as I am more concerned with the meaning of the text and Paleotti's use of singular terms rather than a reproduction of a full coherent text. All translations are the author's unless otherwise indicated, a small number of original italian terms have been left in the text in parentheses when I want to point out a particular use of expression. I have translated the term elevato to here to 'extracted', although it could also mean 'produced' or 'originated from' in this context. See 'elevare' n. 13 in Battaglia 2003, vol. V, 1995, 94. I wish to thank the anonymous peer reviewer for indicating this specfic meaning.

8 "Nel rimirarla spesso mi son venute fatte alcune considerationi, e iscoperti alcuni secreti, chiariti in esso lenzuolo" Paleotti 1598, Unnumbered page in dedication to Pope Clement VIII.

${ }^{9}$ Snyder 2011, 40-45; For the effect of photography on the use of the copies see Geimer and Jackson 2015.

${ }^{10}$ Eriksen 2017; Nagel and Wood 2010.
} 
we use it. Thus, this essay investigates what this relationship between original and copy was in this particular context at this specific time. To do so, this contribution aims to investigate how Paleotti's copy of the Shroud was understood in light of how he described it, and places it in the context of the city of Bologna in the late 1500s. As such it will investigate trust in images from the perspective of two key figures in Bologna in the late 1500s, Ulisse Aldrovandi (1522-1605), natural historian, and Alfonso Paleotti, the second archbishop of Bologna.

While Aldrovandi is often cited for his enthusiastic embracing of images, which he believed could aid the study of the natural world, ${ }^{11}$ Alfonso Paleotti has largely been ignored. One natural reason for overseeing this particular figure, particularly when it comes to image theory or art history, is because he wrote no treatise on images as his predecessor did, nor was he any prolific commissioner of art works. ${ }^{12}$ Yet Paleotti's book on the Shroud demonstrates many of the reasons that Ulisse Aldrovandi praised images so highly. While it may seem unnatural for us to place the religious matters with what we might now term scientific activities, it should be pointed out that the two often went hand in hand in the early modern period. ${ }^{13}$ To be sure, the inquiry into natural phenomenon mentioned in the Bible and the study of ancient remains the earliest Christians were all investigated in a systematic manner in order that they be understood correctly. Bologna is no exception to this tendency. ${ }^{14}$ Indeed, Paleotti's study of the Shroud might even be put into this category; Paleotti's book is not just a devotional treatise, but also an anatomical study of the body of Christ - an autopsy in the modern sense- and can therefore be positioned in the ever-increasing study of natural history and 'historical' Christ. ${ }^{15}$ This study is made through an image - one which Paleotti considers a mediator of truth.

In this article I argue that the truth of Paleotti's copy came from the notion of presence and the ability of the image to make understood that which cannot be comprehended. Focusing on the use of image in the light of early modern natural history rather than on the Shroud as a devotional object, it will reveal that whilst the truth of copies of the Shroud can undoubtably be understood on doctrinal terms, Paleotti's use of the Shroud partakes in the natural

\footnotetext{
${ }^{11}$ Ulisse Aldrovandi to Gabriele Paleotti dated $4^{\text {th }}$ November 1582 'Modo di esprimere per la pittura tutte le cose dell'universo mondo [...]' in Barocchi 1971, 923-930; See also Egmond in this volume.

${ }^{12}$ For existing literature on A. Paleotti see Fanti 1983; Fossati 2001. Alfonso Paleotti's predecessor was Gabriele Paleotti (1522-1597) who is now mostly known for his Tridentine discourse on images published preliminary in 1582.

${ }^{13}$ I use the term 'science' cautiously as the term closest to it in an early modern context was the Latin scientia, which had different connotations to today and tended to pertain more to knowledge or knowing. Scientia was thus not limited to the study of nature, but was used to describe the theoretical side of all disciplines, including theology. On the early modern use of the term see Park and Daston 2006, 3-4.

${ }^{14}$ There are several studies by Aldrovandi which investigate natural and man-made phenomena for interpreting the Bible. One of which was on the Holy Shroud earlier in the 1500s for Gabriele Paelotti, see Biblioteca Universitaria Bologna (hereafter BUB), Ms. Aldrovandi 30 "De ritu sepeliendi apud diversas nationes" / "De sepulchris et condiendis cadaveribus" in two volumes. We also know that Alfonso Paleotti contacted Aldrovandi regarding the investigation of Scripture through natural philosophy in 1577. See BUB, Ms. Aldrovandi 91, "Ulyssis Aldrovandi historia noven gemmarum de quibus fit mention in Ezechiele (cap.28). Reverendissimo ac summa religione praesito Excellentissimoque juriconsulto D. Alphonso Palaeto S. Petri Ecclasiae Cardinalis Canonico Prestantissimo, Ulyssis Aldrovandus philosophus er medicus s.p.d." 383r-409r. For more on this, see Berns 2014, 37-38 n.3.

${ }^{15}$ Pereda 2018, 27.
} 
sciences as much as religion. ${ }^{16}$ Understanding Paleotti's copy in such a way leads us to appreciate why he called his Shroud copy a transunto rather than copy (copia), and in turn sheds light on how such copies, despite their seemingly inadequacies, could convey truth. First though we must turn to Paleotti's use of his copy and what he derives from it in order to understand the potency of the image and the trust he puts in it.

\section{A Modern Autopsy of the Image}

The Esplicatione del lenzuolo was a book which undoubtedly had a devotional purpose at its core; each of the 21 chapters contains analysis of Scripture and is concluded with prayers to the Virgin. In order to support the devotion given to the Shroud, Paleotti departed from the religious aspect of the relic and entered a discourse closer to natural philosophy, anatomy to be precise. ${ }^{17} \mathrm{~A}$ case in point is chapter 16, in which the placement of the nails in Christ's hands is divulged: "In the Shroud" Paleotti explains "it appears that the hands are intact on the outside and the nails did not go through them. Instead the entry wound can be seen in the joint between the arm and hand, called by anatomists the carpo, leaving the hands without exterior wounds". The emphasis is clearly on what he observes in the image of the body. Still, Paleotti uses a logical approach to support what he sees - knowledge of the human body. ${ }^{18}$ Paleotti continues by explaining that this part of the hands is "where the bone is tougher without touching any frontal bones of the same hand". ${ }^{19}$ Paleotti explains rationally that the body could only have been fully supported in this way by the hands alone. Whilst this might be considered one of the most significant discoveries in the Shroud, it is not the only. Through his observations of his copy Paleotti is able to clarify

the quality of the wounds, the shape of the crown of thorns, of the obscuration (darkening) of the face, of the way in which he was nailed in the hands and the feet, the number of nails, the size of the wound in his side, and many other beatings on his head, chest, shoulders and above all the body [persona]..$^{20}$

The author, using his observation of the copy of the image of the body in the Shroud, explains everything from the agonizing pain of the laceration on Christ's back to a clarification of the number of nails used, a much-discussed topic in Christianity, which had however never come to any conclusion. ${ }^{21}$ The emphasis is always on the sense of sight - what can be seen, shown or observed in the image. ${ }^{22}$

\footnotetext{
${ }^{16}$ For such a reading see Kumler 2011; for the political implications of the Shroud copies see also contributions by Cozzo 2019, 104-123; Pérez de Tudela Gabaldón 2019, 313-334.

${ }^{17}$ It must be noted that Paleotti is the first of many to do so, although studies from the 19th century use photographs of the Shroud. See Geimer and Jackson 2015.

${ }^{18}$ It is worth noting that contemporary studies also confirm such information. See for example 'Multimedia reading of the Shroud' in particular 'upper limbs and hands' at www.Sindone.org. https://www.sindone.org/diocesitorino/s2magazine/css/0/sindone_2014/telo/index1.html accessed 29.05.20.

19 “Appare nella santa Sindone ch'elle sono intatte di fuori, e non passate le chiode; ma la piaga della fission loro si vede nella giuntura tra braccio e la mano, detta gli anatomici carpo, rimanedo le mani senza piaghe fi fuori." And "era di piantare il chiodo dove l'osso è piu duro, and senza toccar l'osso di forar l'istessa." Paleotti 1598, 102-104.

${ }^{20}$ Paleotti 1598, unnumbered page in the dedication to Pope Clement VIII.

${ }^{21}$ Pereda 2018, 37.

${ }^{22}$ The verbs vedere, mostrare and osservare are frequently used throughout the book.
} 
Paleotti's observations of the Shroud are controversial, something which he notes himself. He explains both in the main text and in the margins of chapter 16 that observation of the placement of the nails means that there is an "apparent contradiction between the Shroud and that which is said by the Prophets", who indicate that the wounds are in the centre of the hands. ${ }^{23}$ Paleotti realises too that this discovery contradicts centuries of iconographic tradition, as well as a number of famous visions and miracles, such as the stigmata of St. Francis. "How can we approach this difficulty?" Paleotti asks his reader. His answer is to turn to history, as this was the way that the Romans crucified people. ${ }^{24}$ In fact, he continues, there are other sources in Scripture which allude to the oblique path the nails would have made from wrists to the inside of the hand. ${ }^{25}$ A revision of Scripture in light of the Shroud will point to this: "The truth", Paleotti confirms, "is shown clearly by the Shroud, in which the exterior part of the hand is intact without a nail wound". ${ }^{26}$ Those who do not believe the truth "have not seen the Shroud" Paleotti concludes. ${ }^{27}$ In other words, seeing is really believing, or knowing.

What is emerging is that Paleotti's use of his Shroud copy was not solely for devotional purposes but was trusted to give revealing information in the form of what is now, in modern day terms, called a forensic autopsy, a postmortem examination of a corpse to determine the cause of death. This autopsy here is in this case of the tortured body of Christ. The approach to this modern forensic autopsy is, however, through autopsia - the early modern Latin term (from which autopsy derives), as we earlier heard, indicating the method of seeing with one's own eyes. The notion of autopsia would become key for those early modern antiquarians of the $16^{\text {th }}$ and $17^{\text {th }}$ centuries who, like Paleotti, wanted to gain direct and vivid access to history through the remaining fragments and vestiges. To be sure, material sources were so effective that they collapsed time by bridging past and present and generated a living presence known as parousia - a term (adopted from the Greek) which also carried heavy religious implications. Parousia indicated not just the living presence of the past in visual remains, but was also used to describe the appearance, or second coming of Christ. ${ }^{28}$ Parousia also describes the presence of Christ in the Eucharist once consecrated and elevated. Given that the Shroud was believed to be imprinted in Christ's blood it is no wonder that such a presence of Christ was imaginable, even through a copy. ${ }^{29}$

In other words, the reason the copy was fully trusted may well be down to the exceptional nature of the original which, because of the way it was made, its materials and methods, can be said to claim truth albeit not truth as conveyed through visual accuracy. It is to the nature of the original Shroud and to this lack of resemblance that will now turn because this will

\footnotetext{
${ }^{23}$ Paleotti 1598, 102.

24 "Per chiarir questa difficoltà è da presupporre, che presso i Romani l'uso d'inchiodar le mani perché potessero reggere il corpo, era da piantare il Chiodo nel mezzo della mano." Paleotti 1598, 103.

${ }^{25}$ Paleotti 1598, 105.

26 "La quale verità si mostra chiaramente dal Sacro Lenzuolo, nel quale la mano nel parte di sopra è intatta senza piaga di Chiodo." Paleotti 1598, 106.

27 "Si sono ben'accostati alla verità quegli autori, c'hanno tenuto di quattro, quantunque non abbiamo havuto notitia del modo della crocifission de i piedi, per non haver forse ò veduto la Sacra Sindone, ò minutamente avvertito il tutto in quella." Paleotti 1598, 123.

${ }^{28}$ Collinge 2012, 329-330. For the ability to collapse time in material objects see also Nagel and Wood 2010, 32-33.

${ }^{29}$ Bakke 2016, 187.
} 
help to elucidate how the truth could be conveyed through a copy which has little resemblance to the original object.

\section{The Truth of the Shroud}

Comprising of a linen cloth measuring 440 x $110 \mathrm{~cm}$., the Holy Shroud contains the frontal and dorsal image of Christ in the form of bodily imprint (FIG. 5). It is a complex object; considered a bodily relic, a relic of contact, and a 'true image' of Christ. It also falls into a particular category of early Christian acheiropoietic images - those made without human hands - because it was not created by an artist but by a miraculous act of God. The particular way in which this image was made also means it is considered an indexical image, that is, the image guarantees direct contiguous correspondence between the signifier and the signified - in other words, the subject which is represented in the image is precisely that which made the image. As a consequence, the Shroud does not offer a traditional naturalistic portrait, no real resemblance to its prototype, but something more truthful: an image without the use of artistic conventions. This image offers no human mediation, no foreshortening, or use of chiaroscuro but is a portrait, as Paleotti describes, made 'from life' (al vivo). The Shroud is to an extent a visual record of Christ, but it is the image's indexicality which means that it conveys truth. ${ }^{30}$

Yet if indexicality and the image made 'from life' (al vivo) guaranteed the truth of the Holy Shroud, what guaranteed the truth of Paleotti's copy? Paleotti's description of his copy shows us that he had full faith in his copy, yet early modern copies of the Shroud - and, as we will see, also in Paleotti's copy - do not present an exact imitation of the image-relic in Turin. Neither were the copies imprinted nor made by miracles but were produced by artists. The lack of visual accuracy puts into question what guarantees the truth of such a copy for an empirical study, such as an autopsy. As a rule, the truth of such hand-painted Shroud copies is often explained in devotional terms, as coming from the act of making a contact relic, touching it with the original, not from its appearance. These explanations do not however consider the early modern copies of the Shroud as epistemic images, nor do they give full credit to the task the painter of these copies had before them. It is to this discrepancy between original and copy to which we will now look.

\section{Variations on the Holy Shroud}

As several scholars have noted, early modern copies of the Shroud, most likely including Paleotti's, do not look like the original, nor do they even resemble each other. ${ }^{31}$ Almost all the copies contain variations, and none actually look exactly like their prototype (FIGS. 6, 7, 8). In fact, to the modern eye, they present rather rudimentary representations of the image-relic, which may well be down to our habit of knowing the image through photography. ${ }^{32}$ The

\footnotetext{
30 The complex relationship between indexicality, the visual and truth are discussed in Wood 2008. See also DidiHuberman 1984; For more on the indexical image generally see Farago and Preziosi 2012, 98-104.

${ }^{31}$ See the list of differences listed for example by Fossati 1986, 34-35. See also Calabrese's contribution in Molteni 2000; Barta, Carrascosa 2012. My argument here also builds upon Pereda's work which points out the paradox of the artist's ability to deceive in order to represent truth. Here, though, instead of illusion, the artist uses other conventions to convey truth. See Pereda 2018.

${ }^{32}$ Wilson goes as far as to say that some have "the semblance of gingerbread men." Wilson, 2011, 32.
} 
problem of likeness may derive from a distinctive feature of the shroud: one has never been able to see what is represented clearly with the naked eye. One first-hand account of the Shroud from 1578 describes the image in the Holy Shroud as: "very obscured and like a dark shadow, or, like the first sketch for a painting, so that now you see it now you don't". ${ }^{33}$ Artists attempting to recreate life size copies of the Holy Shroud must have struggled to decipher what was to be depicted. In turn the artist was handed over the task of making clear to the viewer what it was that he or she was actually looking at while having to stay true to the idiosyncratic features of the imprinted sheet. The task then was how to make this vague stain recognizable as Christ. The solution was to produce what might be termed 'manipulated copies' - replicas of the Shroud which attempted to convey a visual truth as a negotiation between how the faint idiosyncratic image actually looked and a whole tradition of painted depictions of Christ. Even today this struggle of seeing what the Shroud represents has led to having to manipulate both the original and copies in such a way as to make it more visible. ${ }^{34}$ In the early modern period the struggle between reality and expectation resulted in the copies all differing from each other, so that no one looks the same yet all convey a clearer image than that found in the original. ${ }^{35}$ Early modern artists did this by making Christ's face and features closer to those found in well-known depictions of Christ, in icons and narrative paintings, while also trying to present the figure in a stain-like fashion, flat and without shading or outline - as far away from a painting as possible and still emulating stain. This way of working led to the image of Christ being clearer and easily recognizable whilst also showing Christ as he lay imprinted in the burial sheet, and highlighting the most important features of the Shroud: the five wounds, the burn marks and the distinctive colour. These sharper, although what we might consider 'incorrect' copies (in light of what we regard as precise depictions) all aided the viewer to understand what could be seen in the Shroud.

It is perhaps important here to turn again to Paleotti's use of the word elevato, which he uses as to describe the way his copy has been made from the original. Elevato has been translated so far as 'extracted', but it is worth noting that the term can also be understood in light of the way these images were made clearer and more obvious. The verb 'elevare' can also be used to denote an offering to God, but also to describe the raising of something to a new level so that it be better seen, heard or understood. ${ }^{36}$

With this in mind, it could be argued that the lack of visual accuracy and the rudimentary style of these copies have in fact been misunderstood. This feature is normally dismissed as a result of the copies' function as devotional instruments and not as historical evidence. ${ }^{37}$ But perhaps this is a case of mistaken, or at least limited classification, of such objects. For whilst the copies were, and still are, devotional images, they are also documents providing proof. In Latin the word would have been evidentia, a term in classical rhetoric which denotes clarity,

\footnotetext{
${ }^{33}$ This first-hand account from 1578 by Agostino Cusano is transcribed in BUB Ms. Aldrovandi 30-1.

${ }^{34}$ Most recently the difficulty of seeing the image was dealt with by placing the Shroud in a reliquary which lit the image from behind "that served to enhance the visual contrast of the image to the viewer" see Santa sindone sito ufficiale www.sindone.org. Photography has also manipulated the images of the Shroud to make Christ's imprint more visible.

${ }^{35}$ Fossati 1986, 34-35.

${ }^{36}$ Battaglia 1995, 93-94.

${ }^{37}$ The accompanying text to another, later, Holy Shroud in the Cathedral of Bologna explains that "il telo conservato a Bologna non ha nessun valore documentativo, se non quello di attestare una profonda pietà e devozione per la Passione del Signore." See also Calabreses's contribution in Molteni 2000, 2.
} 
vividness and obviousness. What is now deemed as rudimentary and inexact was in fact a common practice for making complex phenomena clearer and easier to digest through images. In turn, this is exactly the method used for the illustration of the Shroud in Paleotti's book, by means of a lettered key and the removal of 'visual noise', such as the burn marks on the oversized illustrative plate, which helps to provide clarity and obviousness. While also staying as close as possible to the look of the original.

The practice of adapting the way an object really looked through its depiction to make it easier to understand and clearer for the user of the image was common practice in early modern scientific illustration. This practice did not always mean depicting the object as it was seen in the real world but, as Sachiko Kusukawa explains in her study on sixteenth-century scientific illustration, was about "emphasizing key features and selecting out optical confusions". ${ }^{38}$ In other words, what one saw depicted on a page and what one could actually see in the original (if it even existed) did not always correspond. Rather, artists used their skill to make the subject matter more understandable and more convincing. In fact it might help to replace our notion of copy here from 'duplicate' to 'mediation'. The Shroud copies are, to modern eyes, not accurate copies, but copies which made the subject matter - Christ's wounded body - easier to understand, and also more convincing and recognizable.

The accuracy of the copy is not the only challenge to the modern viewer however. Paleotti also states that his copy was "taken from the original" but, as I will show, this statement is also far from what we consider true and undermines the notion that the truth of the copy comes from contact with the original relic. To understand Paleotti's description, we will have to turn again to the fold-out illustration in Esplicatione del lenzuolo.

\section{Una copia elevata fedelmente e diligentemente dall'originale}

Paleotti's life-size copy of the Shroud no longer exists, but we have evidence of how it looked through the illustration in his book. ${ }^{39}$ As noted, one vital detail is missing in this illustration, and it might be argued it is the most visible part of the Shroud: the set of scorch marks which run either side of Christ's body, a result of a fire the Shroud caught in 1532. The reasons for the absence of these marks in the illustration may well have been a choice on behalf of the author or the artist who, as we saw, wanted to make the Shroud's information clearer. It might have been part of Paleotti's own copy though. They were also absent in another copy of the Shroud, namely that belonging of Carlo Borromeo. As Paleotti explains, his Shroud comes through the hands of Federico Borromeo, cousin to Carlo Borromeo. (FIG. 9). Federico Borromeo's copy had not come from the original either but was taken from a personal copy the Savoy family that was made before $1532 .{ }^{40}$ As the Savoy copy was made before the fire it contained no burn marks. Given that Federico Borromeo was the source from which Paleotti received his copy, there is every reason to presume that Paleotti's copy of the Shroud was not taken directly from the original, but from another earlier copy of the Shroud which had in turn been taken from yet another copy originating from the early 1500s made

\footnotetext{
${ }^{38}$ Kusukawa 2012, 7-8.

${ }^{39}$ His copy was left to the 'Monache degli Angeli' in Bologna after his death but no longer exists. See Cingoli et al. 1983, 395.

${ }^{40}$ Cingoli et al. 1983, 395-396.
} 
before the fire of 1532. Perhaps Paleotti chose this other copy as his prototype precisely because it did not contain the marks and was, therefore, visually 'purer', aiding his study of the Shroud through an image.

How should we account for Paleotti's description of his copy as "faithfully and diligently elevated from the original", when it has not been taken from the original but is a copy thrice removed from the prototype? Again, we must move our expectation of what a 'faithful and diligent' copy is and how it might have come from the original. To understand this premise, it will help to place these copies in light of what natural historians regarded as a faithful and diligent image, despite their far removal from the prototype. To investigate such a comparison, we need look no further than Ulisse Aldrovandi who, as we noted earlier had a preference for certain types of images promising the presence of the prototype.

\section{The promise of presence: the image from life}

During the sixteenth century enthusiasm for the study of the natural world and history through material and visual remains grew. At the University of Bologna this tradition for the study of anatomy by seeing for oneself and through images was particularly strong, and had been established at the university with figures such as Berengario da Carpi (1460-1530) who emphasized the study of the body through direct observation. ${ }^{41}$ As we have heard, visual evidence at this time was seen to be able to provide more information than texts alone and could collapse temporal and geographical distance. ${ }^{42}$ Yet it was Aldrovandi, a prominent figure at the university in Bologna and a contemporary to Alfonso Paleotti, who provides some of the most important philosophies about how images might aid natural history and make available natural specimens which were unobtainable. While not writing any theoretical treatises on images, Aldrovandi, in a whole body of correspondence and manuscripts, elaborated on what he considered a trustworthy and accurate image, those made 'from life'.

In a letter to Gabriele Paleotti, Alfonso Paleotti's distant cousin, Aldrovandi notes that images drawn al vivo are of great use for the study of the natural world and they can assist medics in identifying plants. ${ }^{43}$ For Aldrovandi, images made 'from life' were held in high esteem as they guaranteed direct observation of the model. In fact, the term 'from life' in different languages was a pan-European guarantee which promised that the image was "a faithful likeness or a bearer of reliable data". ${ }^{44}$ The term denoted proximity to the subject in appearance as well as in physical presence. ${ }^{45}$ This type of image was discussed most profusely by Aldrovandi.

Paleotti employs the term al vivo on the very first page of Esplicatione del lenzuolo. Describing the image of Christ made in the original Shroud, Paleotti says it is "a principle relic for the image imprinted by Our Lord...represented from life [al vivo]". As we have heard, Paleotti's copy was not made directly from the original but was one in a line of a series of substitutes. How then does his copy convey presence and directness despite it being so far

\footnotetext{
${ }^{41}$ See Olmi and Prodi 1986, 218.

${ }_{42}$ Burke 2003; Parshall 1993.

${ }^{43}$ Barocchi, 1961, 512-515. The letter is dated $5^{\text {th }}$ January 1581.

${ }^{44}$ Balfe et al. 2019, 2.

${ }^{45}$ Swan 1995. See also Groom 2015, 139.
} 
removed from its model? That is, how can it be made 'from life' when clearly it was far from it?

\section{Good copying mechanisms}

Angelica Groom, in her study on the topic of the al vivo, argues that many of the images depicting natural phenomenon and said to be made al vivo, were in fact far from it. Images claiming to be made al vivo could be copies of other images but gave the impression of direct observation. These images were in fact often depictions which have gone through an aesthetic interpretation in order to convey the appearance of seeing the object in life. ${ }^{46}$ This could be conveyed through the artist's attention to texture, colour or composition, as well as to other details. Jacopo Ligozzi (1547-1627), one of Aldrovandi's preferred artists due to his ability to depict nature vividly, demonstrates this. By emphasizing the outward characteristics of the specimen such as texture and composition, the artist gives the impression that the image is made 'from life'. Yet a large number of the images claiming to be made al vivo in Aldrovandi's collection were not created in this way at all. Rather they were copies of other images made in that way. These copies were sometimes many times removed from the original observational drawing and were often by other artists than the one who made the original observation. They were still very much valued as worthy epistemic images, offering a way to study unavailable phenomena.

This might be demonstrated with an image of a pineapple Aldrovandi requested from the Medici court by Ligozzi and found in Aldrovandi's collection (FIG. 11). Aldrovandi's pineapple presents a clear copy of the original image still now present in Florence where Ligozzi worked (FIG. 10). The impression of texture and use of colour in the depiction of the rare exotic fruit clearly expresses what Aldrovandi admired in Ligozzi's work. Yet Aldrovandi's pineapple image was clearly a copy of another image and maybe even by another artist. ${ }^{47}$ The truth of these images came from artistic conventions which made the subject matter seem present and the promise that at some time they had been observed closely by an artist.

We should not presume that the receiver of these 'copies of copies' was deceived in any way into thinking that the images were closer to the real thing. It appears that Aldrovandi had complete knowledge that many of the images he considered al vivo were copies of other images. Essentially, argues Groom, Aldrovandi actively encouraged it. ${ }^{48}$ This is because these types of images of rare and strange phenomena could provide a sense of parousia, creating the presence of the object so it could be studied in its absence. The pineapple or the burial shroud of Christ is a case in point.

Understood in this way, it becomes clear that for Paleotti a copy three times removed from its original, could well convey a sense of presence of the subject given that the original was created al vivo in the presence of Christ. The presence in the copy was created through artistic conventions which persuaded the viewer that what they were seeing was an eye-witness account. What had to be conveyed in this case was an image which was not created by artistic conventions but was in fact a stain, which had to be recognizable as Christ. Paleotti clearly

\footnotetext{
${ }^{46}$ Groom 2015, 143.

${ }^{47}$ On the 'al vivo' quality of the pineapple by Ligozzi see Markey 2017.

${ }^{48}$ Groom 2015, 146.
} 
valued the al vivo quality of the original Shroud, yet he never uses it to describe the copy of the holy burial sheet but uses another term. This word also guarantees the presence of the prototype in the copy and in turn the truth conveyed in it.

\section{Copy as Transunto}

As we recall, Alfonso Paleotti describes his request for a copy of the Shroud as a transunto rather than copia. ${ }^{49}$ The term transunto accommodates well the discussions above on how Paleotti's copy of the Shroud could be at once "faithful and diligent" as well as "from the original" when, for the modern onlooker this does not seem to be the case. It describes well how the presence of the original, maybe even Christ himself, could be seen in the copy although far removed from its prototype, and having no exact resemblance.

Transunto is a now rarely used Italian word which is a synonym for 'summary' or 'compendium'. ${ }^{50}$ Translated into English as 'transumpt', transunto can also be defined as a copy or transcript of a record, deed or other legal document as well as 'pictorial representation'. ${ }^{51}$ In this light, transunto is an image which carries weight as documentation or evidence. It is a copy which is deemed trustworthy for re-presenting a transaction, legal documents or events, as attestation, and is sometimes with a seal as certification.

Transunto's other related meanings as 'summary' or 'compendium' should not be overlooked either as it may explain the lack of resemblance between original and copy. 'Summary' is defined as "the essence or essential part of something; the real or essential meaning". 52 As I have indicated, the copies of the Shroud offered no exact copy of the relic but a negotiation between what was expected and what could be seen. They are made elevato from the original, which as we saw, meant to accentuate and clarify what was presented. These early modern copies of the Shroud also presented a summary, of the most essential information in the Shroud. Thus the 'transumpt image', (if we call it that in English) may well have been considered evidence of something offering an official 'summarized' version of that visual information the Shroud revealed. To be sure the use of the terms elevato and transunto seem to indicate this.

The etymology of transunto also assists to further understand how Paleotti's copy of the Shroud could communicate the image al vivo and Christ's living presence. The prefix 'trans' comes from the action of 'taking across' and the second component '-unto', literally means 'to unite or combine into one'. It is apt here to recall the term Parousia which as we saw, indicated living presence, in particular of Christ through the Eucharist. The term transunto then correctly describes the way in which, like through the image of the Eucharist, the original and copy are in fact unified despite their distance and their dissimilarity. Alfonso's copy carries the event of the image made al vivo by Christ, from the Shroud in Turin, to the hands of Paleotti in Bologna, and perhaps in turn even to the reader who unfolds the book's illustration. Just like the term al vivo, the noun transunto offers a promise of the original act of mak-

\footnotetext{
49 'Copia' in the Renaissance often meant copiousness or variety rather than copy. See Cave 1979.

${ }^{50}$ Also spelt transumtto, trassunto, transuto. Battaglia 2002, Vol. XXI, 176.

${ }^{51}$ I might be noted that this use was mainly in Scotland from the sixteenth-century to c. 1870. See 'Transumpt' in Oxford English Dictionary.

52 'Summary' in Oxford English Dictionary.
} 
ing the image from life in a copy which is far-removed from the original. For the Holy Shroud this act of carrying across and transmitting the presence of Christ in the Shroud was crucial; concealed from human eyes for almost all its life, except for the few days, every few years, when it was taken out for private and public expositions. The need for other images to make it visible and understandable was vital.

While I have limited my discussion here to a copy of the Holy Shroud in Bologna from the late 1500s, there is still need to explore early modern meanings of copies both in light of devotional and scientific needs and uses. I hope to have shown that the transunto was no mere copy. It carried legal connotations and represented the most important visual information found in the original. It also permitted an understanding of an image which is at the same time devotional and epistemic. Transunto promised an image which could be trusted as a mediator of truth. The analysis of the terms Paleotti used to describe his copy have assisted in understanding how he could trust a hand painted copy of the Shroud despite its shortcomings to the modern eye - how despite the lack of resemblance and the term 'faithfully and diligently extracted from the original' can be understood.

As recent discussions about models of substitution and performance have highlighted, the fine line between forgery and copy, images made from direct observation and those made from copies in medieval and early modern period, require a more nuanced vocabulary and require further study. ${ }^{53}$ As we have seen, Alfonso Paleotti's description of his copy of the Holy Shroud in contrast to the aesthetics of these copies shows there is still much to be understood. In an age where truth and how it is communicated to us through images is becoming ever more uncertain, the need for a way to describe this repertoire of objects we term merely 'copy' is becoming vital. Whether these copies be far removed from the original, manipulated copies, copies which emulate presence or 'visual transumpts', they require a broader vocabulary for which, terms such as transunto, deserve to be investigated further.

Samantha L. Smith

University of Bergen

samantha.smith@uib.no

\footnotetext{
${ }^{53}$ For a selection of literature on the understanding of copies of images in the early modern period see the bibliography to this contribution, in particular Nagel and Wood 2010; Wood 2008; Groom 2015.
} 


\section{BIBLIOGRAPHY}

\section{MANUSCRIPTS}

(BUB- Biblioteca Universitaria di Bologna)

BUB Ms. Aldrovandi 91. "Ulyssis Aldrovandi Historia noven gemmarum de quibus fit mention in Ezechiele (cap.28). Reverendissimo ac summa religione praesito Excellentissimoque juriconsulto D. Alphonso Palaeto S. Petri Ecclasiae cardinalis canonico prestantissimo, Ulyssis Aldrovandus philosophus er medicus s.p.d." 383r-409r.

BUB Ms. Aldrovandi 30. Two volumes. De ritu sepeliendi apud diversas nationes and De sepulchris et condiendis cadaveribus. Begun c. 1578.

\section{LITERATURE}

Bakke J. 2016: "Et in Arcadio Ego: Poussin and early mdoern visual historia", in Images of knowledge: The epistemic lives of pictures and visualisations, $\mathrm{N}$. Vaage, R. Slaattelid, T. Haagensen et al. (eds.), Frankfurt am Main: Peter Lang GmbH.

Balfe T., Woodall J., Zittel C. (eds.) 2019: Ad vivum?: visual materials and the vocabulary of life-likeness in Europe before 1800, Leiden, Boston.

Barocchi P. (ed.) 1971: Scritti d'arte del Cinquecento, (La Letteratura Italiana. Storia e Testi 32), v. 1, Milano-Napoli.

Barocchi P. 1961: Trattati d'arte del Cinquecento, fra manierismo e controriforma. V.2. Gilio - Paleotti Aldrovandi, Bari.

Barta C., Carrascosa A.V. 2012: "The Shroud of Turin and its ancient copies", Scientific research and essays, 7 (29), 2526-2544, https://doi.org/10.5897/SRE12.284.

Battaglia S. 2003: Grande dizionario della lingua italiana, v. 21, Torino.

Battaglia S. 1995: Grande dizionario della lingua italiana, v. 5, Torino.

Berns A. 2014: The Bible and natural philosophy in Renaissance Italy: Jewish and Christian physicians in search of truth, New York.

Burke P. 2003: "Images as Evidence in SeventeenthCentury Europe", Journal of the History of Ideas 64.2, 273-296.

Cave T. 1979: The Cornucopian Text : Problems of Writing in the French Renaissance, Oxford.
Cèsar B. 2012: "The Shroud of Turin and its ancient copies”, Scientific Research and Essays 7.29.

Cingoli G., Coppini L., Fanti M. 1983: "Le copie della Sindone conservate in Bologna", in La Sindone: scienza e fede. Atti del II, convegno nazionale di sindonologia, Bologna, 27-29 nov. 1981, Bologna.

Collinge W.J. 2012: Historical Dictionary of Catholicism, Lanham, Md.

Cozzo P. 2019: "A Relic to See and Touch: the Sensory Dimension of the Shroud in Court (XVI-XX Centuries)", in Cozzo P., Merlotti A., Nicolotti A. (eds.), The Shroud at court: history, usages, places and images of a dynastic relic, Leiden, 104-123.

Daston L. 2015: "Epistemic images", in A. Payne (ed.), Vision and Its instruments: art, science and technology in early modern Europe, University Park, Pennsylvannia.

Didi-Huberman G. 1984: "The index of the absent wound (monograph on a stain)", October 29, 63-81.

Eriksen A. 2017: "Copies, concepts and time", Culture unbound: Journal of current cultural Research 9.1, 6-22.

Eriksen A. 1988: "Voglia di paradiso: mistici, pittori e committenti a Bologna fra Cinquecento e Seicento", in A. Emiliani (a cura di), Dall'avanguardia dei Carracci al Secolo Barocco: Bologna 1580-1600, Bologna.

Fanti M. 1983: "Genesi e vicende del libro di Alfonso Paleotti sulla Sindone", in L. Coppini, F. Cavazzuti (a cura di), La Sindone, scienza e fede. Atti del II convegno nazionale di sindonologia, Bologna 27-29 novembre 1981, Bologna.

Farago C., Preziosi D. 2012: Art is not what you think it is, (Blackwell manifestos), Chichester.

Fossati L. 2001: "Un'opera sulla Sacra Sindone bestseller del Cinquecento", Collegamento pro Sindone, April.

Fossati L. 1986: "Copies of the Holy Shroud parts II and III: undated copies and synthesis of the research", Shroud spectrum international 13, 23-39.

Geimer P., Jackson G. 2015: “A self-portrait of Christ or the white noise of photography? Paul Vi-gnon and the earliest photograph of the Shroud of Turin", Grey Room 59, 6-43. 
Groom A. 2015: "Early modern natural science as an agent for change in naturalist painting: Jacopo Ligozzi's zoological illustrations as a case study", in D. Beck (ed.), Knowing nature in early modern Europe, (Warwick series in the Humanities 5), London.

Kumler A. 2011: "The multiplication of the species: eucharistic morphology in the Middle Ages", Res: Anthropology and Aesthetics 59-60.1, 179-91.

Kusukawa S. 2012: Picturing the book of nature: image, text and argument in sixteenth-century human anatomy and medical botany, Chicago.

Markey L. 2017: “Aldrovandi's new world natives in Bologna (or how to draw the unseen al vivo)", in E. Horodowich, L. Markey (eds.), The New World in early modern Italy, 1492-1750, Cambridge.

Molteni F. 2000: La memoria di Cristo: Le copie della Sindone : verità di fede e verità storica, Siena.

Nagel A., C.S. Wood. 2010: Anachronic Re-naissance, New York.

Olmi G., Prodi P. 1986: “Art science and nature in Bologna circa 1600", in National Gallery of Art (U.S.), Pinacoteca nazionale (Bologna, Italy) and Metropolitan Museum of Art (New York, N.Y.) (eds.) 1986: The Age of Correggio and the Carracci: Emilian painting of the sixteenth and seventeenth centuries, (Exhibition Catalogue), Washington.

Paleotti A. 1598: Esplicatione del lenzuolo, oue fu inuolto il Signore, e delle piaghe in esso impresse col suo pretioso sangue confrontate con la Scrittura, Profeti, e Padri. Con la notitia di molte piaghe occulte, e numero de' chiodi. Et con pie meditationi de' dolori della B. Verg.ne. Dell' ill.mo e R.mo Mons. Alfonso Paleotto Arciuesc. di Bologna ad utilità spirituale del suo popolo, Bologna: Per gli heredi di Giovanni Rossi.

Park K., Daston L. 2006: "Introduction”, in K. Park, L. Daston (eds.), The Cambridge History of Science, v.3. Early Modern Science, New York.
Parshall P. 1993: "Imago Contrafacta: Images and Facts in the Northern Renaissance", Art History 16.4, 554-579.

Pereda F. 2018: Crime and Illusion: The Art of Truth in the Spanish Golden Age, London.

Pérez de Tudela Gabaldón A. 2019: "15 Copies of the Holy Shroud for the Court of King Philip II of Spain (1527-1598)", in P. Cozzo, A. Merlotti, A. Nicolotti (eds.), The Shroud at court: history, usages, places and images of a dynastic relic, Leiden, 313-334.

Snyder J. 1980: "Picturing Vision", Critical Inquiry 6.3, 499-526.

Swan C. 1995: "Ad Vivum, Naer Het Leven, from the Life: Defining a Mode of Representation", Word and image 11. 4.

Wilson I. 2011: The Shroud, London.

Wood C.S. 2008: Forgery, Replica, Fiction: Temporalities of German Renaissance Art, Chigago.

\section{ONLINE SOURCES}

Commissione Diocesana per la Sindone 2020: Multimedia reading of the Shroud <https://www.sindone.org/diocesitorino/s2magazine/css/0/sindone_2014 /telo/index.html> Accessed 29.05.20.

Oxford English Dictionary: The Definitive Record of the English Language, Oxford. <http://www.oed.com> Accessed 01.06.20.

Turley K.V. 2019: "The Shroud of Turin: Latest Study Deepens Mystery", in National Catholic Register. 05.08.2019. <http://www.ncregister.com/dailynews/the-shroud-of-turin-latest-study-deepensmystery> Accessed 29.05.20. 


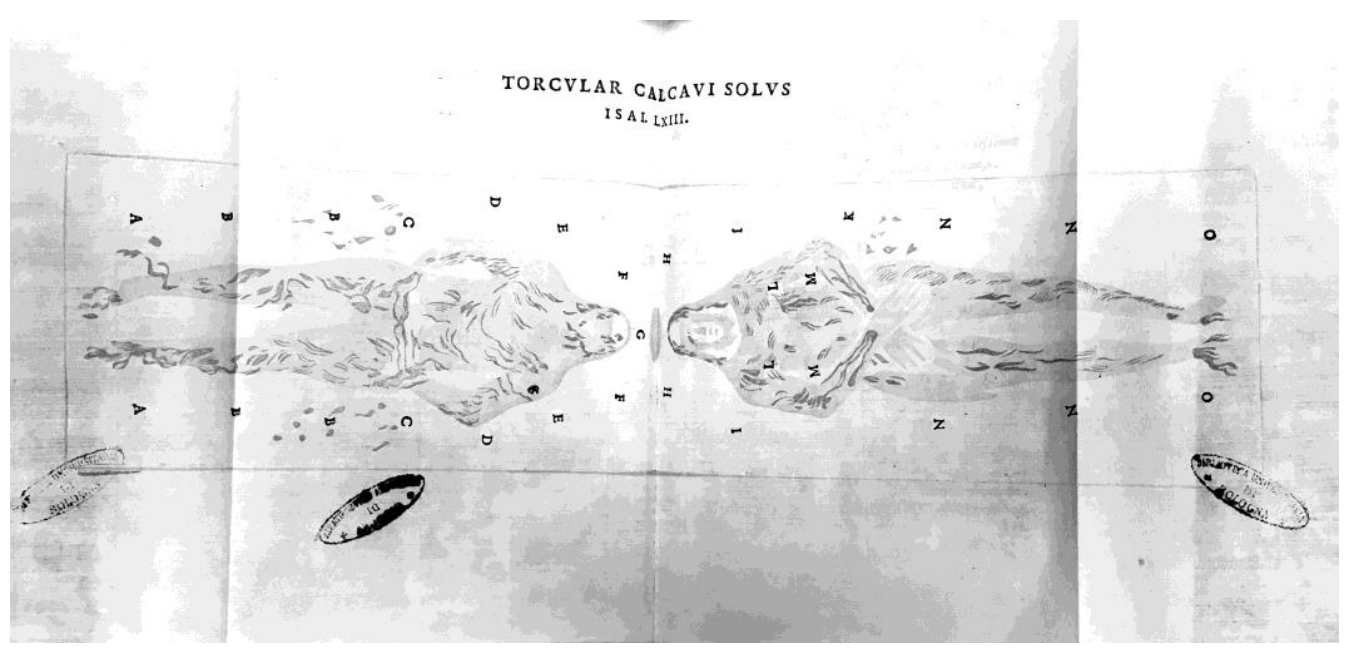

FIG. 1 - The fold-out illustration of the Holy Shroud from Esplicatione del Lenzuolo [...]. 1582. Artist: unknown. Woodcut on paper. Photo: author. Image printed with permission of Biblioteca Universitaria di Bologna.

$4^{\circ}$

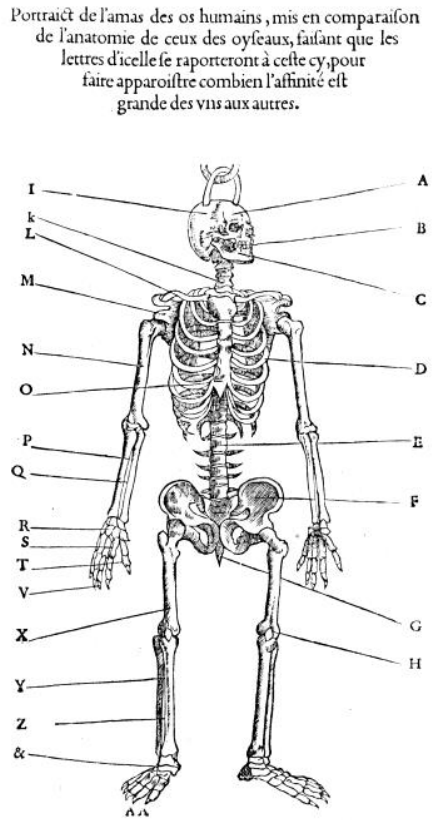

DES OYSEAVX, PAR P, BELON.

La comparaifon du fufdit portraie des os humains monftre combien ceftuy cy qui eft d'vn oyfeau,en eft prochain. Portraict des os de l'oyfeau.

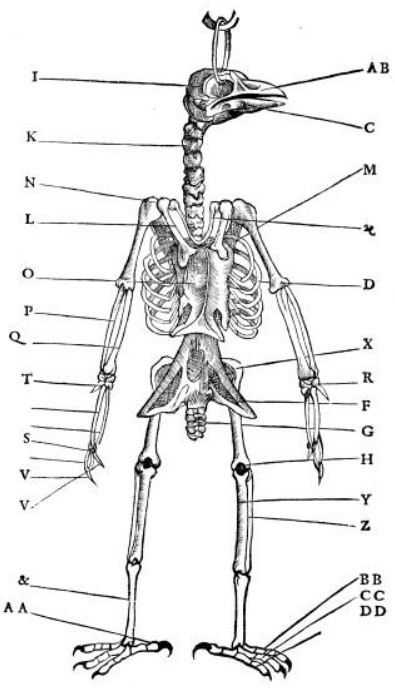

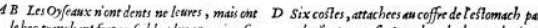

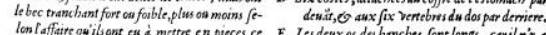

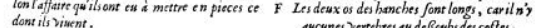
dont is vituent.

$M$ Deux pal
cun cosite.

$H$ La roselle du genoil.

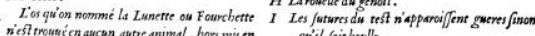

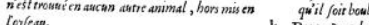

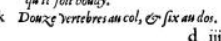

FIG. 2 - A comparative anatomy illustration using the tool of a lettered key in Pierre Belon's L'Histoire de la nature des oyseaux (1555). Artist: unknown. Woodcut on paper. Image: Public domain. 


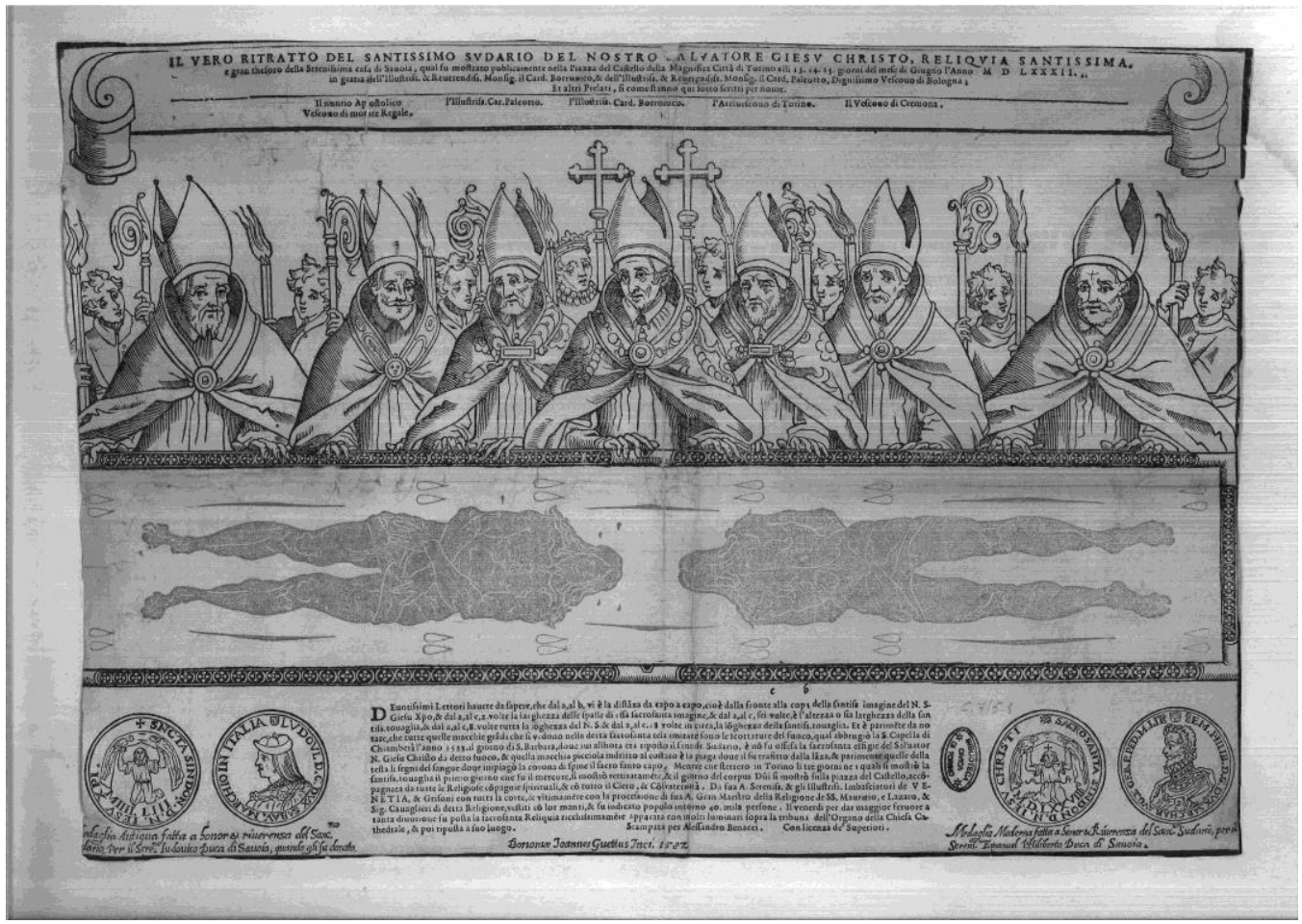

FIG. 3 - An announcement for the ostension of the Holy Shroud of 1582, attended by Carlo Borromeo, Gabriele Paleotti, the first Archbishop of Bologna and Alfonso Paleotti. Artist: Joannes Guettu. 1582. Etching and woodcut. Image: courtesy of Biblioteca Civica Torino.

FIG. 4 - An image of Alfonso Paleotti venerating the Holy Shroud outside the city of Bologna, unnumbered page, in Esplicatione del Lenzuolo [...]. c. 1598. Artist: Francesco Brizio after a drawing by Lodovico Carracci. Etching. Photo: author. Image printed with permission of Biblioteca Universitaria di Bologna.

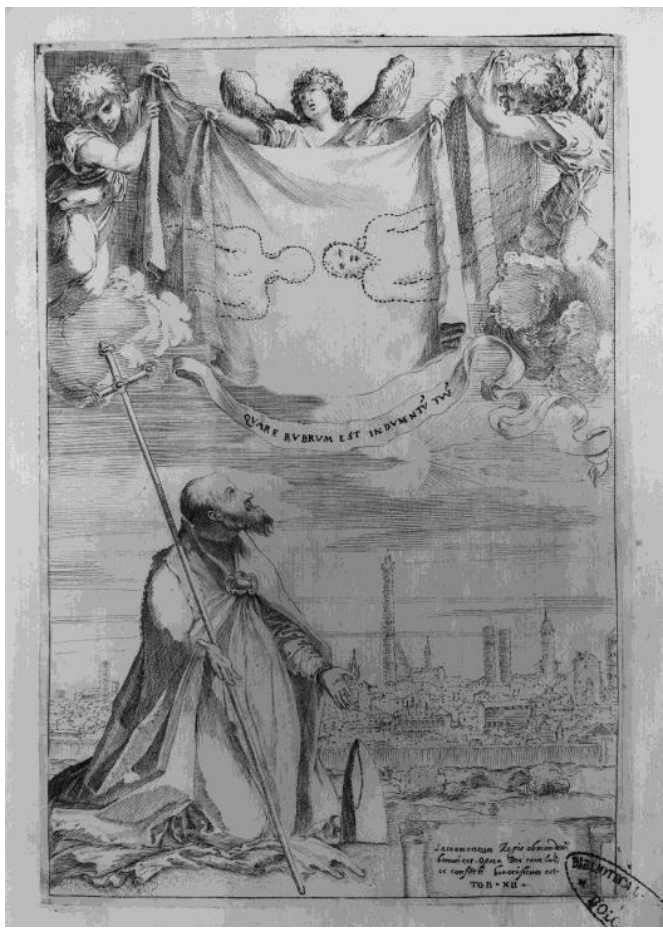




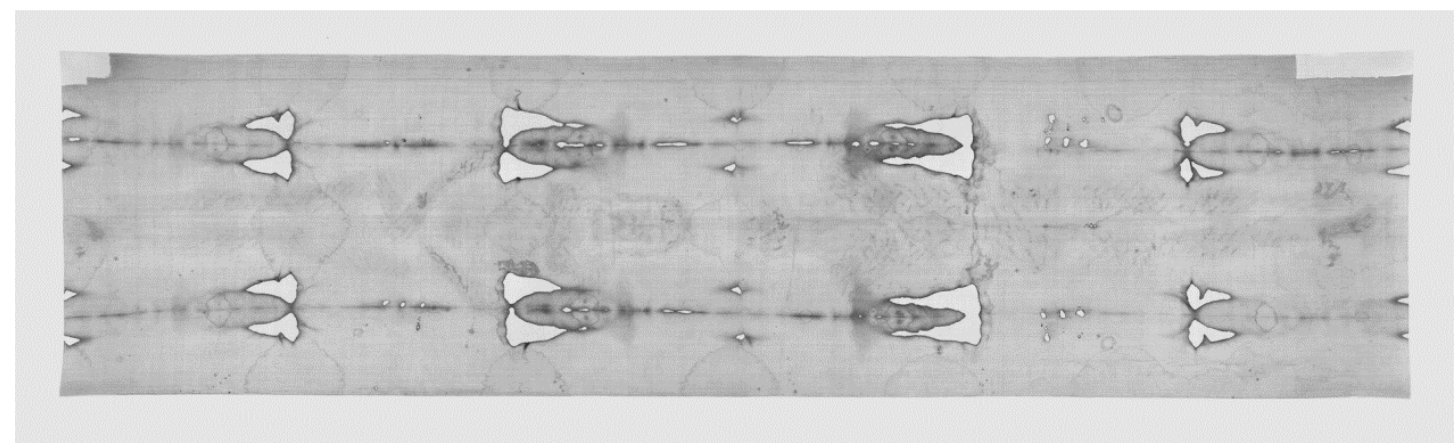

FIG. 5 - Positive photograph of the Holy Shroud. Late $21^{\text {st }}$ century. Photo: Giandurante, Copyright: Arcidiocesi di Torino. Image: courtesy of Commissione Diocesana della Sindone.

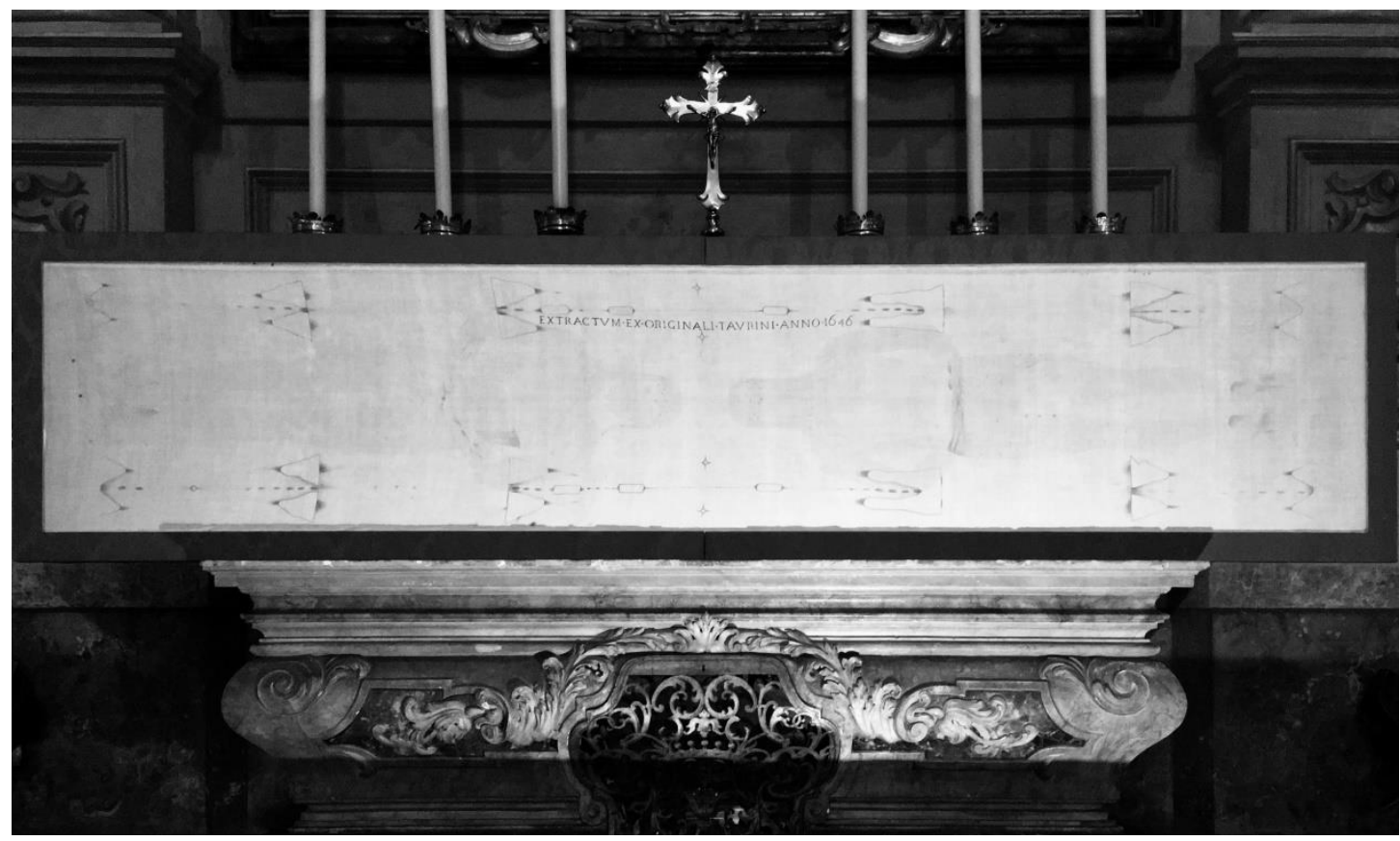

FIG. 6 - A 17th-century life-size painted copy of the Shroud, now in Bologna Cathedral. Artist: Attributed to Maria Apollonia di Savoia. 1646. Tempera and French black stone on linen. Photo: author. 


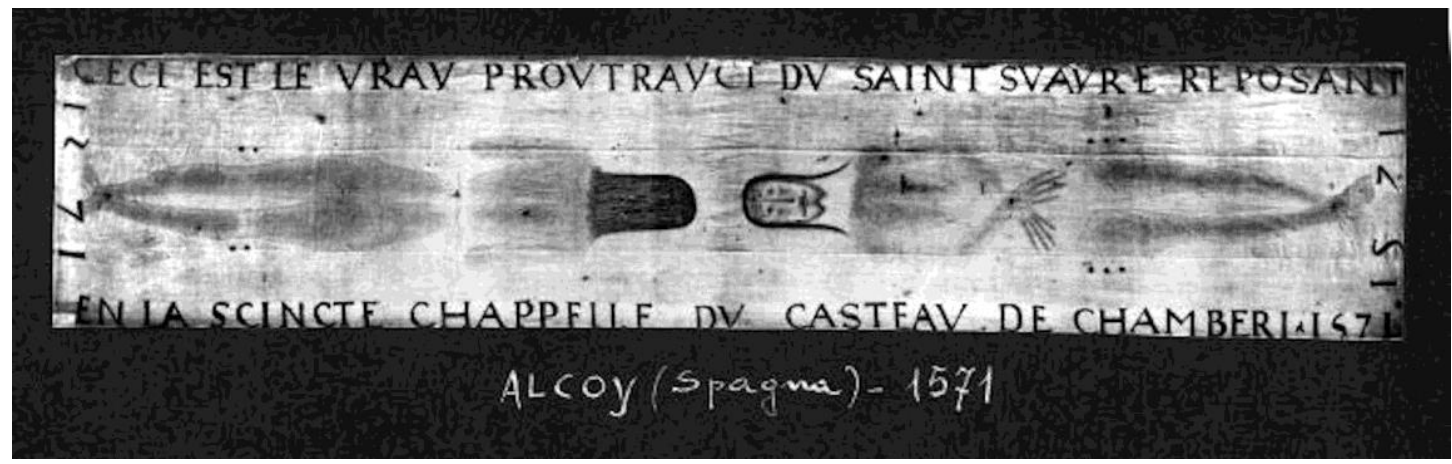

FIG. 7 - A life-size hand-painted copy of the Holy Shroud from 1571 now in Alcoy, Spain. Unknown artist, c.1571. Image: Public Domain, courtesy of Manuela Marinelli.

FIG. 8 - A $17^{\text {th }}$-century life-size painted copy of the Holy Shroud at San Guida Taddeo, Rome, c.1692. Artist unknown. Photo: Author.

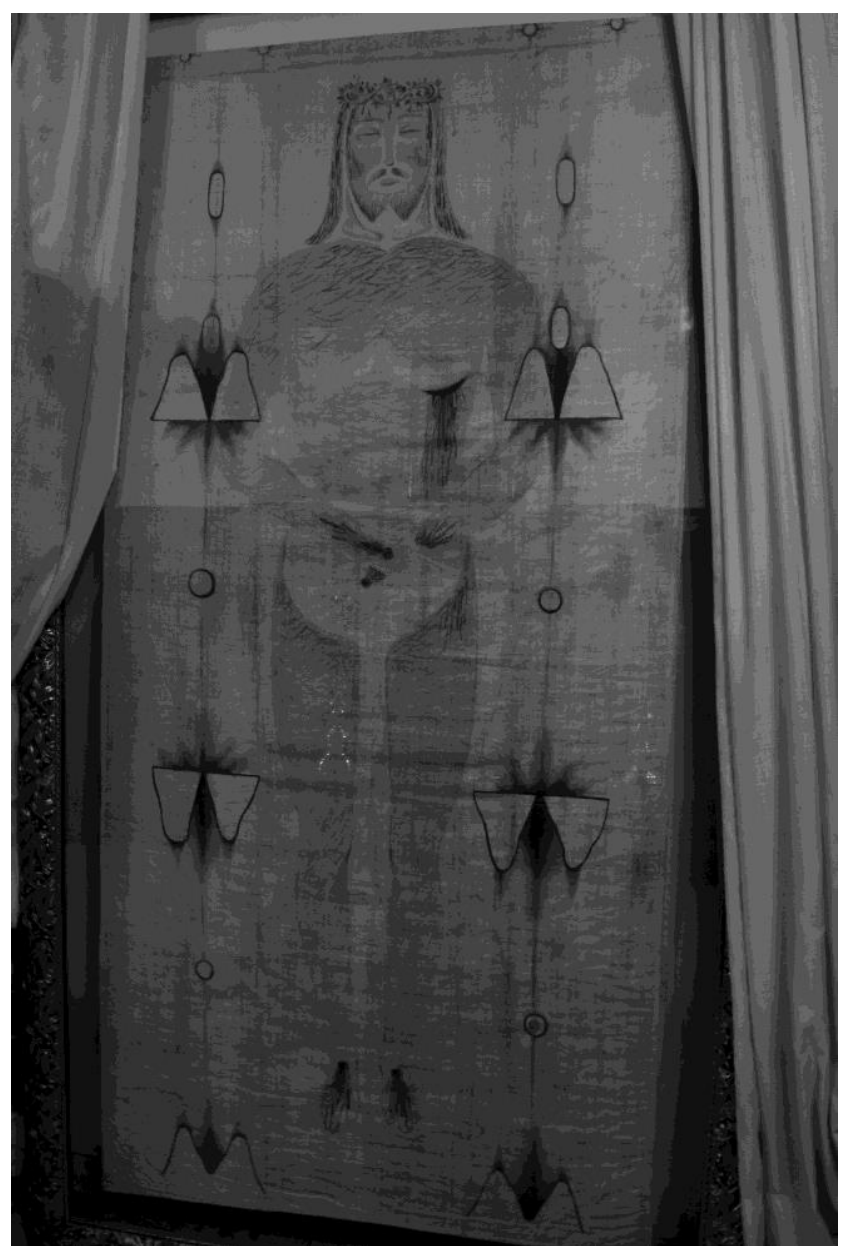




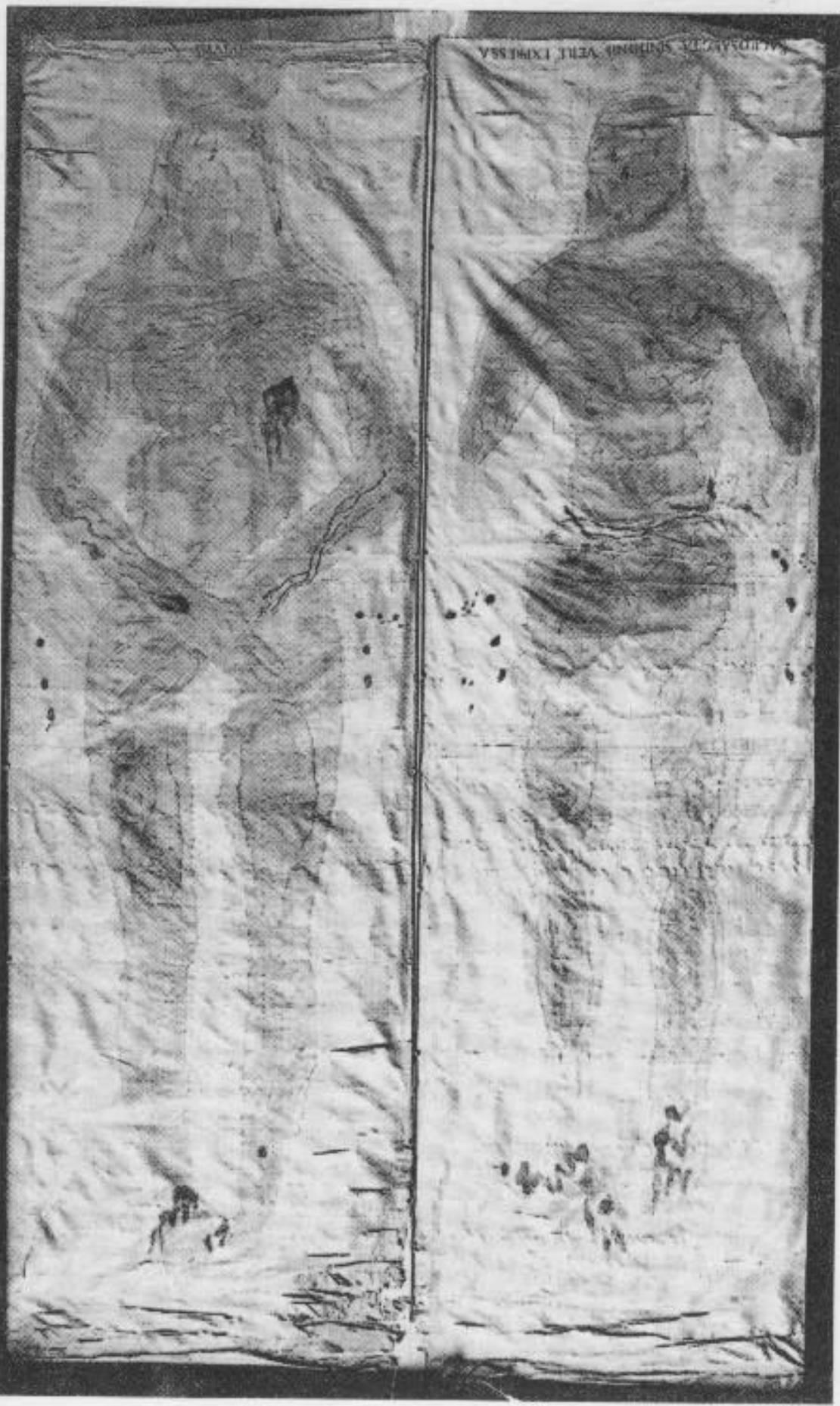

FIG. 9 - Carlo Borromeo's copy of the Shroud cut in two, now known as 'The Shroud of Inzago', with an inscription which reads 'Sacrosancta Sindonis vere impressa imago' Unknown artist. c.1581. Image: courtesy of Giovanni Mapelli. 


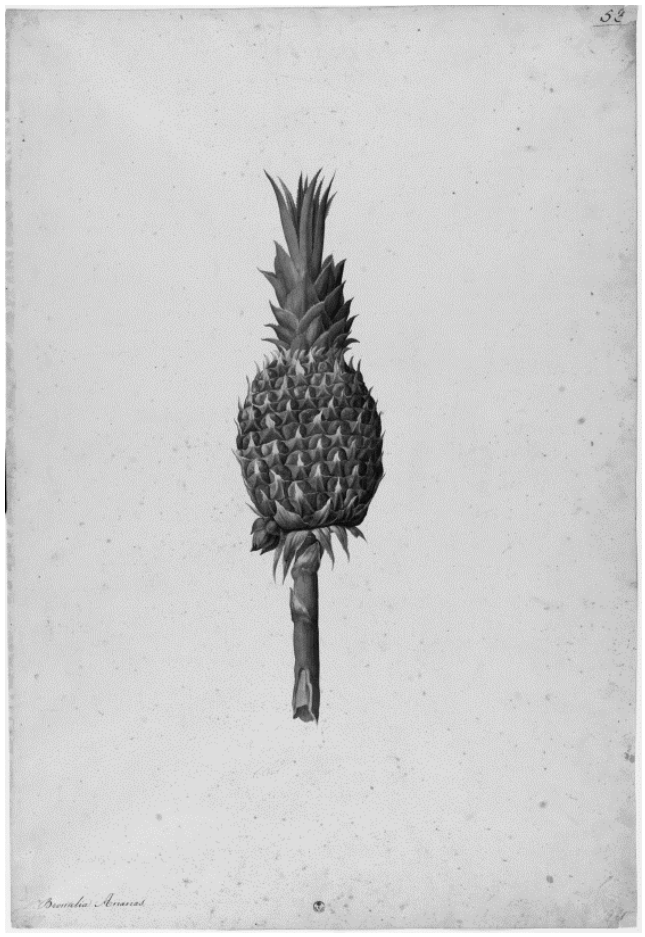

FIG. 10 - The original illustration of Bromela Ananas (inv1931 O). Artist: Jacopo Ligozzi. Watercolour. Late $16^{\text {th }}$ century. $675 \times 461 \mathrm{~mm}$. Gabinetto dei disegni e delle stampe della galleria degli Uffizi. Image: courtesy of Le galleria degli Uffizi.

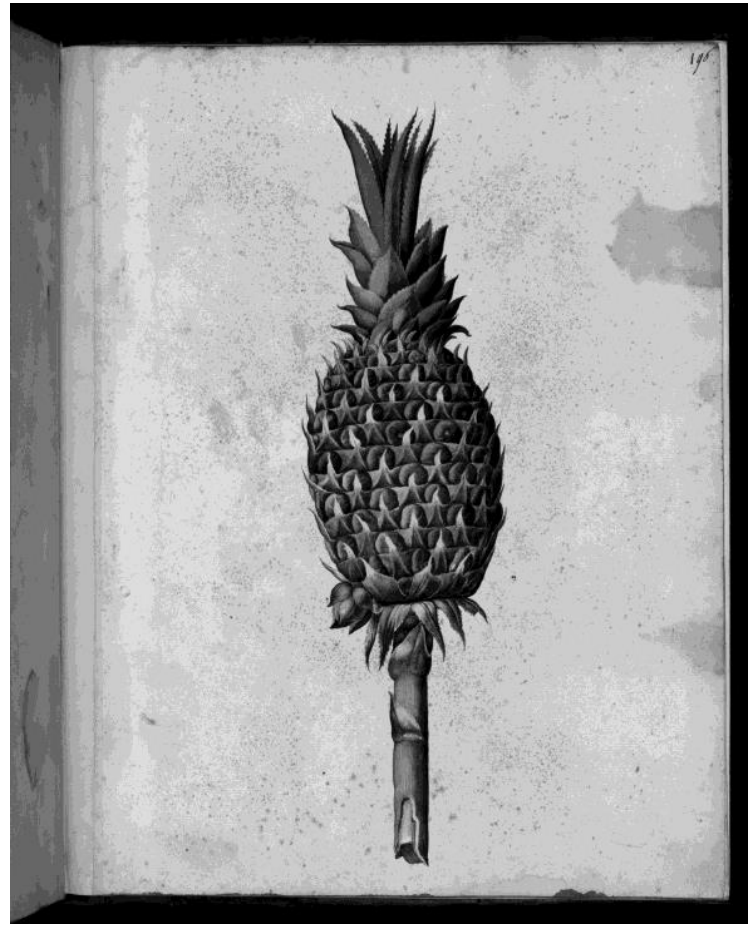

FIG. 11 - Ananas in Aldrovandi's image collection (A later copy of Jacopo Ligozzi's original Bromela Ananas image which is now at the Uffizi). Artist: Jacopo Ligozzi. Watercolour. Second half of the $16^{\text {th }}$ century. $465 \times 360$ $\mathrm{mm}$, tav 3 carta 196a. Biblioteca Universitaria di Bologna. Image: courtesy of permission of Biblioteca Universitaria di Bologna. 
